\title{
Fetal Stem Cells in Farm Animals: Applications in Health and Production
}

\author{
P. S. Yadav $\cdot$ R. K. Singh $\cdot$ B. Singh
}

Received: 15 October 2011 / Accepted: 5 December 2011/Published online: 19 January 2012

(C) NAAS (National Academy of Agricultural Sciences) 2012

\begin{abstract}
Scientifically validated embryonic stem (ES) cell lines in species other than mice, humans and some primates are not yet established. New insights into biological properties, and ease of derivation make fetal and adult stem cells play a vital role in livestock health and production. The placenta and fetal adnexa (such as umbilical cord blood, umbilical cord matrix, amnion and fetal fibroblasts) are immensely valuable sources of pluripotent and progenitor cell lineages. The fetal cells are easily accessible in larger quantities, and can be used for various applications including assisted reproduction, regenerative medicine or production of induced pluripotent stem cells. The fetal stem cells due to expression of pluripotency markers and sharing similar growth kinetics to ES cells, provide strong support to the notion that they may be biological homologues to ES cells.
\end{abstract}

Keywords Fetal stem cells · Pluripotency $\cdot$ Livestock applications

\section{Introduction}

The stem cells are defined by two properties. First, progeny arising from division may retain stem properties, a process termed self-renewal. Second, progeny of stem cell division may lose capacity for self-renewal, and can either differentiate or enter into a series of terminal divisions, finally yielding an organized tissue. Besides unprecedented role in basic, developmental biological and biomedical science, the stem cell technology is emerging as promising area to enhance animal production and biodiversity conservation [54, 67]. Literature clearly demonstrates that despite two

P. S. Yadav

Central Institute for Research on Buffaloes, Hisar 125001, India

e-mail:psyadav@scientist.com

R. K. Singh

National Research Center on Equines, Hisar 125001, India

e-mail: rks_virology@ rediffmail.com

B. Singh $(\bowtie)$

Indian Veterinary Research Institute, Regional Station,

Palampur 176 061, India

e-mail: bsbpalampur@yahoo.co.in decades of research on animal ES cells, the "proven" stem cell lines are not yet reported [61]. The major hurdles include lack of information on species-specific mechanism regulating cellular pluripotency, and differences in basic mechanisms of embryonic development among mammalian species [62]. It has also been mentioned that murine ES cells arise from egg cylinder stage embryos, and this stage is lacking in domestic livestock embryos, and that epiblast morphology is also different in rodents and ruminants [1].

Various attempts have been made to establish ES cell lines for economically important livestock species $[58,65$, 68]. In view of technical and ethical concerns to establish ES cells, establishing fetal stem cells could be a promising alternative approach. The fetal stem cells can be derived either from fetus proper or from the supportive extraembryonic structures that are of fetal origin (Fig. 1). Extraembryonic tissues-serving as sources of pluripotent stem cells, include umbilical cord blood, umbilical cord matrix, amniotic fluid (AF), amniotic membranes and the placenta [2, 9, 31, 32].

Due to being extra-embryonic, available in bulk quantity and easy to access, the fetal and adult stem cells are being 
Fig. 1 Types of fetal stem cells based on their origin. The features and applications of the cells vary depending on sources and the culturing milieu provided

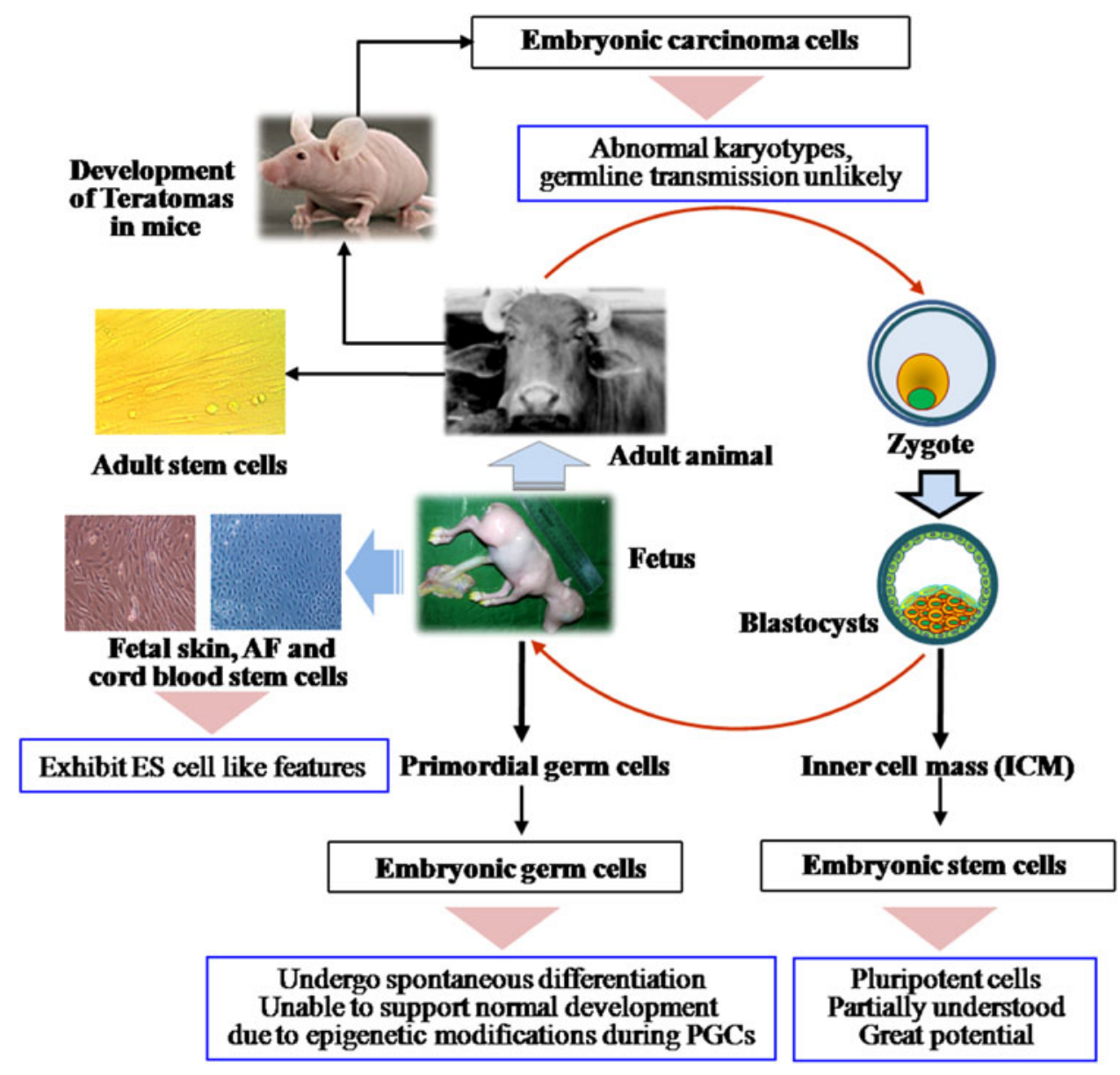

largely investigated in animals. In addition, the fetal and adult stem cells sources can provide novel insights into the developmental biology of the animals. Also, the fetal stem cells may represent readily available sources of pluripotent stem cells for applications in preclinical studies in large animals, and developing models to evolve future human therapies [33].

The three criteria used to define mesenchymal stem (MS) cell in humans - as proposed by the Mesenchymal and Tissue Stem Cell Committee of the International Society for Cellular Therapy (ISCT)_include (1) the MS cells must be plastic-adherent when maintained in vitro; (2) MS cells must express CD73, CD90 and CD105, and lack expression of CD34, CD45, CD14 or CD11b, CD79 $\alpha$ or CD19 and MHC class II antigens; (3) The MS cells must differentiate into osteoblasts, adipocytes and chondroblasts in vitro. The progress of fetal cells in livestock is reviewed to assess how far the humans MS cells defining criteria are met by various animal species as the lack of a single specific marker for MS cells and the limited or no availability of monoclonal antibodies constituted the major stumbling block in the characterization of livestock MS cells as per the guidelines of ISCT. This review presents state-of-the- art of fetal stem cells in domestic animals and their prospects in livestock production and health. An overview of avian stem cells and their applications to enhance poultry production and biopharming has been presented. Wherever necessary, the relevant examples of human fetal stem cells have also been cited.

\section{Pursuit of Fetal Stem Cell Research in Livestock}

Certain large animal models being more close to human physiology and anatomy can serve as a model which can mimic the human physiology and anatomy, and therefore, provide one step ahead of mouse model for rapid transition of discoveries from murine models into clinical therapies and interventions [11]. The stem cell technologies developed in model animals can serve as a baseline to develop stem cell treatments for humans wherein many injuries (tendon and ligament damage) and diseases (myocardial infarction, stroke, osteoarthritis, osteochondrosis, and muscular dystrophy) can be targeted in large animals, and also in humans [6]. The fetal sources such as umbilical cord, amnion and AF have been proposed as ideal sources 
of different stem cell lineages. Use of adnexal tissue has many potential advantages, including the non-invasive isolation and large tissue mass yielding stem cells. However, the differentiation potential of these cells, either in vivo or in vitro, is intermediate between the pluripotent ES cells and the multipotent adult stem cells, yet these cells have opened new perspectives for developmental biology and regenerative medicine in humans as well as in veterinary medicine [9]. The promises that fetal stem cells offer include regeneration of tissue for injuries for which natural repair mechanisms do not deliver functional recovery, and for which current therapeutic strategies have minimal effectiveness [47].

Stem cells have been used for studies of heart disease in dogs, although it has been mainly used as a model for ischaemic heart disease in man [34]. Unlike humans, most other mammals including dogs, do not suffer naturally occurring clinical ischaemic heart disease, so the relevance of this research for clinical veterinary medicine is limited. However, other cardiac diseases such as canine dilated cardiomyopathy might be appropriate candidate diseases for this therapy in future [47].

Effect of transplanted MS cells from the Whartons's Jelly (WJ) of caprine umbilical cord on wound healing revealed that re-epithelisation was complete in 7 days in treated wounds, whereas in control the wounds showed incomplete epithelisation even after 12 days of wounding. Microscopic evaluation showed less inflammation, thinner granulation tissue formation with minimum scar in the treated wounds in comparison with control wounds, elucidating the beneficial effect of caprine WJ cells on cutaneous wound healing [2]. Rachakatla [46], while studying migratory nature of human umbilical cord matrix stem (UCMS) cells, observed migration of UCMS cells towards
MDA 231 human breast carcinoma cells in an in vitro model of cell migration when UCMS cells were cultured with or without MDA 231 cells for $24 \mathrm{~h}$. UCMS cells were found to migrate towards MDA 231 cells in a dosedependent manner. These results suggest that MDA 231 cells might be releasing chemokine factors, such as SDF-1 and VEGF, which promote UCMS cell migration towards the tumor cells in vitro. Stem cells that migrate to tumors may allow targeted delivery of therapeutic agents that otherwise may have severe side effects. These results indicate that UCMS cells can potentially be used for targeted delivery in cancer therapeutics [46].

Further, stem cells from farm animals such as pig, cattle, sheep, goat, or horse can be useful for improving animal health and will also facilitate the development and validation of animal models for evaluating stem cell-based therapies. The applications of stem cells in livestock are specific for every species depending upon the economic importance, utility of animals and their use in human or biomedical sciences (Table 1). Overstrain injuries to weight-wearing tendons are common in human [21, 52], and equine [20,49], with many similarities between the two [12, 66]. Injury of Achilles heels in human athletes and superficial digital flexor tendon (SFDT) in athletic horses bears total similarities. While investigation of cell-based therapeutics generally reflects human medical needs, the high degree of frequency and severity of certain injuries in race horses has put veterinary medicine at the forefront of this novel regenerative approach [63]. According to a report, injuryinduced failure of horses to compete in the races for which they were bred and trained costs the racehorse industry an estimated US\$6.5 billion per year [64].

It has been reported that utilizing a cell line having greater plasticity and proliferative capacity than adult

Table 1 Applications of fetal stem cells to livestock health and production

\begin{tabular}{|c|c|c|}
\hline $\begin{array}{l}\text { Sl. } \\
\text { No }\end{array}$ & Species & Potential applications (references) \\
\hline 1 & General & $\begin{array}{l}\text { Animal model, human clinical therapies and interventions application }[11,57] \text {, Applications in veterinary regenerative } \\
\text { medicine [2], derivation of various cell types from naturally occurring pluripotent or iPS cells, developing cell lines/cell } \\
\text { cultures for isolation and growth of viruses }[9,31,32,41] \text {, conservation of genetic diversity through repopulation of } \\
\text { endangered species/cells for cloning/transgenic and iPS cell production }[39,54] \text {. }\end{array}$ \\
\hline 2 & Canine & Canine dilated cardiomyopathy, and canine spinal injuries, and canine diabetes [47] \\
\hline 3 & $\begin{array}{l}\text { Equine/ } \\
\text { Camel }\end{array}$ & Ligament and tendon repair, laminitis $[17,64]$ \\
\hline 4 & $\begin{array}{l}\text { Cattle, } \\
\text { buffaloes }\end{array}$ & $\begin{array}{l}\text { Enhancing milk and meat production Enhancing biopharming through transgenic milch animals; reduction in emissions of } \\
\text { green house gases; production of meat in vitro }[38,54,56]\end{array}$ \\
\hline 5 & Pig & $\begin{array}{l}\text { Developing cells, tissues and organs for xeno-transplantation, enhancing biopharming through transgenic animals, } \\
\text { production of pork in vitro [38] }\end{array}$ \\
\hline 6 & $\begin{array}{l}\text { Goats and } \\
\text { sheep }\end{array}$ & $\begin{array}{l}\text { Enhancing biopharming through transgenic animals, in vitro mutton/chevon production, conservation of genetic diversity } \\
\text { through repopulation of endangered species }[2,33]\end{array}$ \\
\hline 7 & Poultry & $\begin{array}{l}\text { Production of vaccines and various therapeutics, minimizing release of nutrients into environment, enhancing feed } \\
\text { utilization through transgenic birds }[30,35,48]\end{array}$ \\
\hline
\end{tabular}


multipotent MS cells may better contribute to tendon regeneration [7]. As such, fetal stem cells have by now been explored by many research groups who have demonstrated efficient isolation, expansion and differentiation in vitro $[8,66]$. Thus, the limitation of adult MS cells and controversy on use of embryonic MS cells is prompting the scientific fraternity to demonstrate the use of fetal MS cells in clinical therapy as these cells have some characteristics of embryonic cells left in them. In equines, the stem cells can have great applications for treatment of laminitis and repair of ligaments and tendons. Various researchers have been studying the use of MS cells in cellular therapy in the treatment of tendonitis [17]. In high producing dairy animals homologous stem cells can have applications in treating the mammary tissue damaged by mastitis. However, the efficacy and safety of these treatments and the basic characteristics of stem cells used remain largely unknown and need further studies [26].

\section{Major Types of Stem Cells in Animals}

Presently, three types of stem cells have been described: ES cells of the early embryos, adult stem cells, and fetal stem cells from extra-embryonic tissues. The important considerations to facilitate stem cell applications in veterinary medicine include the ability to collect large numbers of cells in an inexpensive and non-invasive ways without risk to the donor, and their proliferation and cryopreservation [4]. The isolation and identification of stem cells in the amniotic membranes has been promising in the field of cell therapy. Recently, the first results have been published demonstrating the clinical efficiency of the stem cell in the healing of pancreatic, cardiac, lung and neuronal lesions [51].

\section{Embryonic Germ Cells}

The embryonic germ (EG) (Fig. 1) cells are different from the somatic cells, and give rise to gametes. This immortality raises the question of how and when EG cells are set aside from the somatic cells and how they are maintained during development until differentiation into gametes [59]. During development, precursor germ cells are created in one part of embryo, often far away from their final destination. They then migrate to the somatic part of the future gonads, where they become mature germ cells [28]. Genetic analysis of fruit flies, zebrafish, and mice have led to the identification of several genes that are required for primodial germ cell migration. It has been reported that a pair of evolutionarily conserved molecules-the protein SDF-1 and its receptor CXCR4- act to guide PGCs in zebrafish [25]. Unlike ES cells, animal experiments on EG cells have been limited, but it is assumed that the range of potential fates will be relatively limited compared to ES cells. However, the main advantage of EG stem cells is that they do not generate tumors when transferred into the body. This may make them potentially useful sources of transplantation and cell-based therapies.

\section{Amniotic Fluid Stem Cells}

The AF, due to being a safe, reliable, and simple screening tool is widely used for numerous basic and biomedical applications. The AF comprises of normal embryonic or fetal chipping cells derived from the three germ layers (ectoderm, endoderm and mesoderm) [5], it possesses the natural precursors of all differentiation lineages.

The recent isolation of cells with stem cell features from $\mathrm{AF}$, opens many new venues including regeneration of tissues and ultimately even organs [14, 42]. AF stem cells of early gestation seem to express higher levels of endodermand mesoderm-specific markers compared with those of later gestation, while ectodermal markers show no difference [43]. These are clonally expended in MS cells that exhibit a series of stem cell-specific markers including Oct-4, Nanog and SSEA-4 and have a wide range in differentiation potential. Recent reports suggest that AF stem cells might have additional benefits. The deployment of AF stem cells for tissue regeneration offers advantages over the use of ES or adult stem cells, viz., (i) AF represents a convenient and non-contested source for obtaining stem cells; (ii) isolating them is relatively simpler and rapid; (iii) no feeder layers are required for their culturing; (iv) they display no spontaneous differentiation in culture; and (v) their stem cell phenotype is not affected by long-term storage [24] (Fig. 2).

The AF cells in water buffaloes collected from young fetuses (50-70 days) maintained a characteristic round shape, then (80-100 days gestation) changed to cells with different morphologies including spherical cells with nucleus, spherical cells without nucleus, polygonal cells, and freely floating cells (Fig. 3) [10, 70]. The AF cells were found to expand without feeder layer over a period of 100 days (up to passages 20), and overexpress the AP, Oct4 , Nanog and Sox-2, GAPDH, and $\beta$-actin [70]. These features are also noted in human AF cells [22]. It has been concluded that bubaline AF cells could be cultured and maintained in vitro for a prolonged period and offer a potential source of multipotent cells for applications like therapeutic assisted reproduction in animals [70].

\section{Amniotic Membrane Cells}

The cells of the amnion show features of multipotent stem cells and have been proposed for use in cellular therapy and regenerative medicine [8]. The amniotic membrane (AM) is of fetal origin. It is a thin avascular membrane composed 
Fig. 2 The morphologically different types of bubaline $\mathrm{AF}$ cells (a), namely, spherical with large nucleus 1 , pentagonal with nucleus 2 , and spherical but enucleated 3. The cultured AF cells (b) show anchorage dependent growth and expression of AP
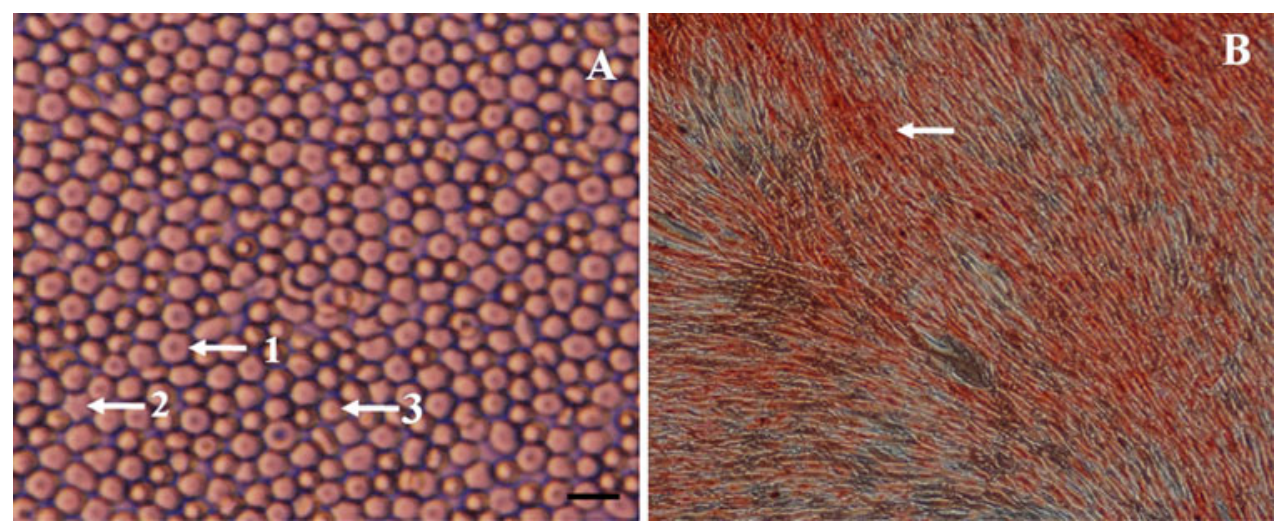

Fig. 3 Derivation and applications of animal fetal stem cells. The bubaline AF and WJ cells have been found to express pluripotency genes, and may possibly be differentiated into various types of cells

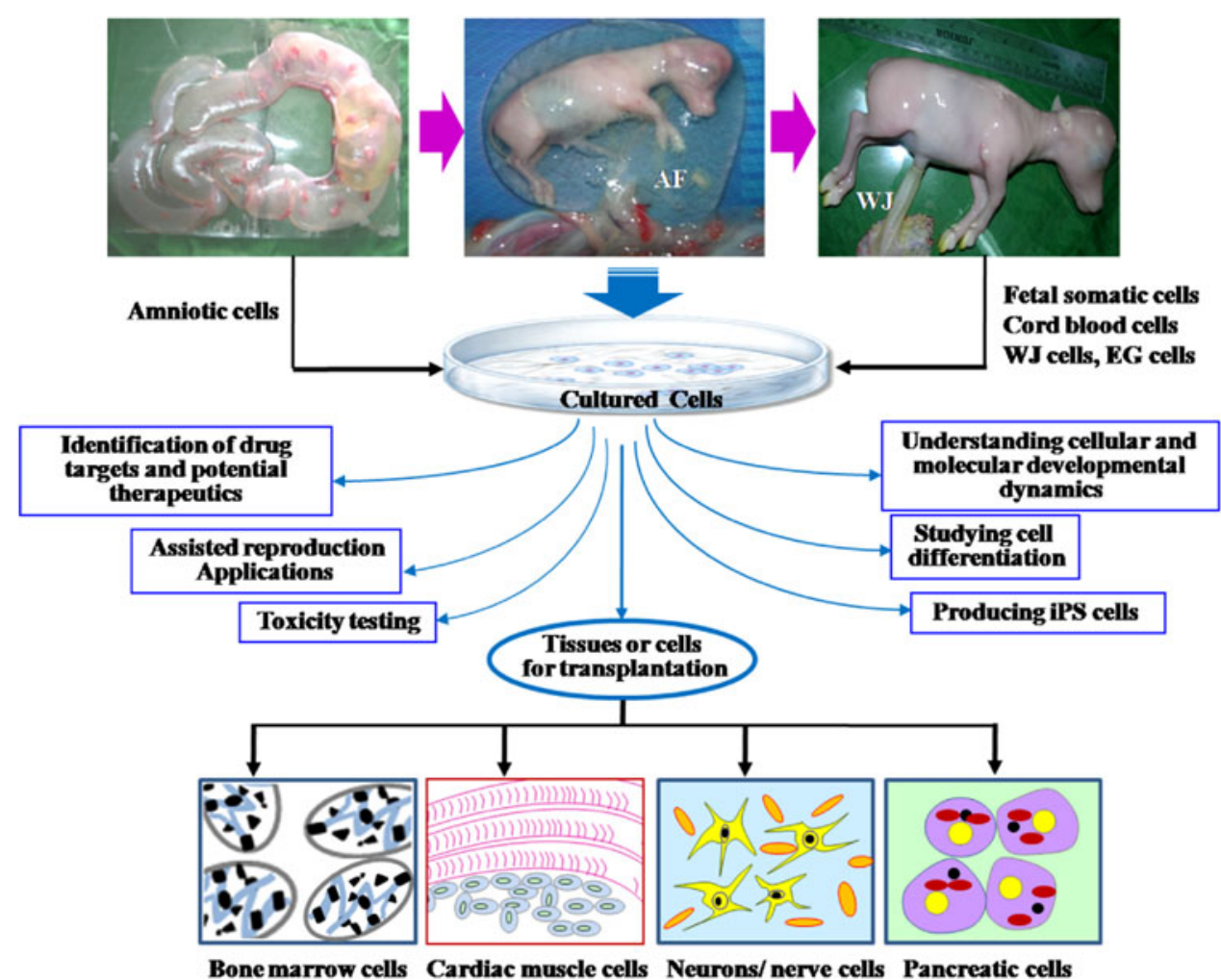

Bone marrow cells Cardiac muscle cells Neurons/nerve cells Pancreatic cells of an inner epithelial layer and an outer layer of connective tissue and is contiguous, over the umbilical cord, with the fetal skin [3].

The bubaline AF have been found to exhibit polygonal shape and completed 21 passages in 75 days of continuous culture and expressed Oct $4[10,70]$. The AM and cells derived from it are positive for AP, Nanog, Oct-4 and Sox-2 over expression. In equine, the differentiation induction for pancreatic and osteogenic cells yielded oil red O-positive cells for pancreatic and alizarin red positive for osteogenic cells. The technique for sampling, isolation, and expansion of equine AF stem cells forms a basis for establishment of a database for collecting and preserving stem cells used in the field of equine regenerative medicine [8].
Samandari et al. [50] used human AM as healing accelerator and bone induction in dogs. The AM decreased fibrinileukocytic exudates, inflammation and suitable experimental cover for different injuries and further acellular AM has the potential for rapid improvement and bone induction. The AM contains collagen, laminin and fibronectin which provide an appropriate substrate for bone induction. This substrate has been reported to promote bone induction and might contribute to induction of progenitor cells and/or stem cells in the area where it had been undertaken and has also differentiated into bone.

The AM-derived cells have potential for osteogenic, adipogenic, chondrogenic and myogenic differentiation in vitro, thus can have potential for use as engraftment 
material [45]. As fetal tissue is usually discarded after birth, it involves no ethical concerns if it is used as source of MS stem cells. Equine amnion has further advantages for use in stem cell work as it is a rich and easily accessible source of MS cells, as equine amnion is easy to sample immediately after birth and is not attached with the rest of the placenta [8].

\section{Fetal Fibroblasts and Stem Cell-Like Cells}

Stem cell-like multipotent stem cells have been noted in the abattoir-derived fetuses of water buffaloes [70]. Recent reports indicate that the pluripotency genes expressed by ES cell are also expressed by fetal fibroblast. In this direction, the expression of AP, Oct 4 , Sox $2 \mathrm{~A}$ and $\mathrm{B}, \beta$-actin GAPDH, and Nanog has been detected in bubaline fetal fibroblasts [70]. The murine and porcine fetal explants cells have also been found to express the pluripotency genes [27]. It was shown that fetal somatic explants contain a subpopulation of somatic stem cells, which can be induced to display features of lineage uncommitted stem cells. After injection into blastocysts, fetal fibroblasts cells differentiated into a variety of cell types including those of the mesodermal lineage; they even migrated into the genital ridge. In vitro, the fetal stem cells exhibit characteristics of ES cells, including extended self-renewal; expression of Oct 4 , Stat3, and Akp2 (Tnap) and growth as multicellular aggregates [27]. This indicates that fetal tissue contains stem cells with greater potency than previously thought, hence, might serve as a new source of animal stem cells.

\section{Umbilical Cord Blood Stem Cells}

The umbilical cord is a noncontroversial source of mesenchymal-like stem cells. The umbilical cord blood (UCB), which is normally discarded, can be easily collected at the time of delivery [16]. Collection can be accomplished by venipuncture of the umbilical vein of the placenta still in utero, or after the expulsion of the placenta itself. Advantages of UCB stem cells are their high proliferative capacity, low risk of viral contamination response to alloantigen, their availability and donor safety. However, there are limited reports on the cord blood from livestock; main limitation in collection of cord blood in livestock including equines is breakage of the umbilical cord during parturition.

In normal calving, after expulsion of the placenta, small quantity of cord blood (5-6 ml) could be collected. Morphology of buffalo umbilical cord blood, new-born calf blood and adult buffalo blood revealed that cord blood parameters differed significantly from new-born calf and adult buffalo blood.

In equine, UCB had significantly lower total erythrocyte (RBC) count, total leucocyte (WBC), lymphocyte, and granulocyte count than those of mare and foal. While RBC count was the highest in foals, WBC, lymphocyte and granulocyte counts were highest in mares followed by foal and UCB, respectively. Hemoglobin, percent hematocrit values and platelet count were the least in UCB, followed by mare and foal blood. Unlike buffalo, equine UCB is more intimate to mare blood, as there was significant difference in eight parameters in UCB and foal blood out of 18 parameters. In man, horse, cattle and dogs umbilical cord blood-MS cells have multipotent abilities. UCBderived stem cells in domestic animals are capable of differentiation in vitro, not only toward mesenchymal cell lineage (osteogenic, chondrogenic, myogenic and adipogenic), but also toward endodermal (hepatogenic) and ectodermal (neurogenic) lineages under appropriate culturing conditions [9].

\section{Wharton's Jelly Stem Cells}

The umbilical cord provides stem cells in two compartments: umbilical cord blood (UCB) and umbilical cord matrix, also known as Wharton's jelly (WJ) (Fig. 4). Besides, humans [15], the stromal cells with certain pluripotency markers have also been reported from $\mathrm{WJ}$ of pig [4] and buffalo (Yadav PS, unpublished results).

The WJ surrounding the two arteries and single vein of umbilical cord has been observed in buffaloes. The salient features of buffalo cells from WJ include sticky jelly-type tissue, slow growing primary colony (8-10 days embedded cells, spikes formed but not as clear as fibroblasts and passage time is 3-4 days) [69]. Bubaline cord matrix cells could be cultured for more than 100 days in continuous cells culture which expressed Oct-4, Nanog and Sox [69]. The identification of the WJ as an alternative source of MS cells provides significant clinical benefits viz., harvesting, reduction of risks associated with transmitting infections, acceptable level of HLA mismatch [55].

\section{Placenta Stem Cells}

In transition from morula to balstocyst, first differentiation takes place in the ICM cells and the trophectoderm. ICM forms the epiblast and the fetus in early development as well as is the source of ES cells. The trophectoderm forms the placenta which supports and protects the developing fetus. The stem cells populations derived from human placenta tissues are chorionic mesenchymal stromal cells and the chorionic trophoblastic cells, both demonstrating variable plasticity [40]. The cells from the placental tissues exhibit the markers of pluripotency (SSEA-4, oct-4, Stro-1 and TRA 1-81) which are typical mesenchymal markers and have capacity of a wide range of differentiation. They are capable of in vivo differentiation into various types of 
Fig. 4 Wharton's jelly. a Diagrammatic presentation [29]. b TS of bubaline WJ showing blood vessels embedded in the matrix. The matrix could be a promising source of MS cells
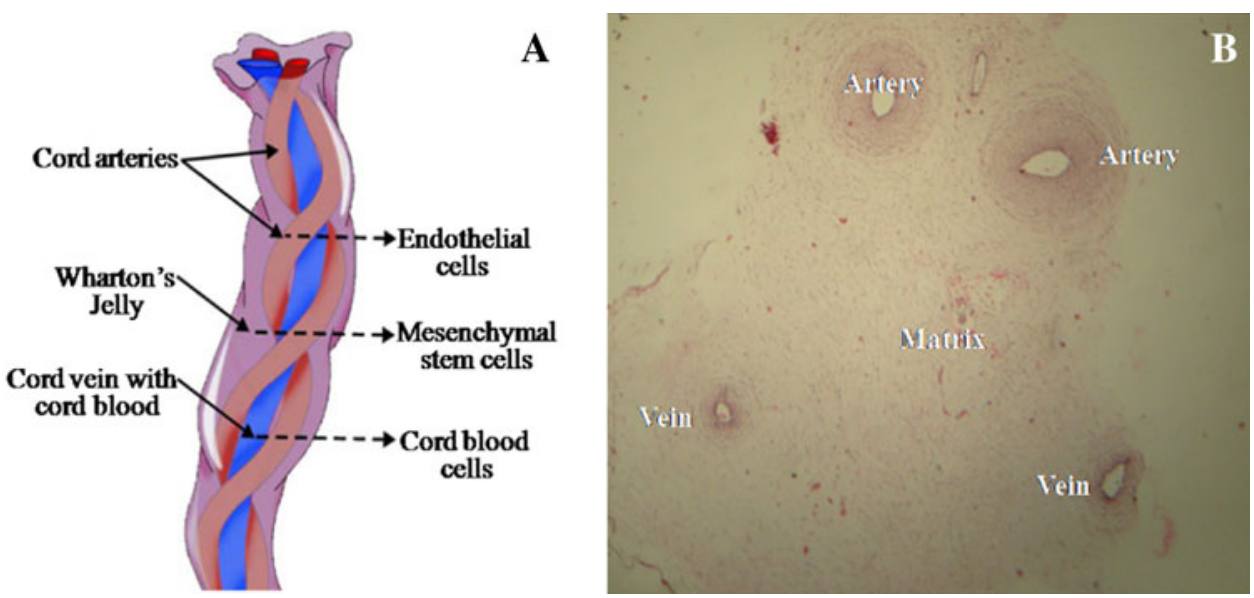

cell lineages if seeded in scaffolds [40]. The pre-treated placenta-derived human MS cells with a hyaluronan mixed ester of butyric and retinoic acid could cure infracted pig hearts. The treated pigs in comparison to untreated infracted pigs had $40 \%$ smaller infarct scar size and a significant improvement of end- systolic wall thickening and circumferential shortening of the infarct border zone. Scarce reports on animal placenta cells suggest that further work on this source is required [53]. The authors have also highlighted the necessity of using combined diagnostic imaging to avoid under-estimations of therapeutic effects of porcine stem cells in cardiotherapy.

\section{Induced Pluripotent Cells from Somatic Cells}

Nuclear reprogramming of the adult somatic cell to a state of developmental pluripotency or multipotency [60], has generated enormous hopes in cell biotechnology, human and veterinary diseases, and production of genetically engineered livestock. The iPS cells and reprogrammed cells can be exploited for both research and clinical applications. The technology to establish pluripotent stem cells from domestic ungulates, viz., buffaloes, cattle, sheep, or goats would be beneficial for biopharming and would facilitate the production of recombinant pharmaceutical proteins in animals [37].

Neither true pluripotent ES cell lines nor EG stem cells have been reported so far in farm animals. It is still not clear whether this is due to deficiencies of the current in vitro culture conditions, which do not support proliferation of farm animal-derived stem cells and maintenance of pluripotency, or it is due to the lack of knowledge about the factors regulating stem cells isolated from species other than human and rodents [18]. However, none of the cell lines reported so far withstood the stringent in vivo pluripotency tests such as teratoma formation and the ability to contribute to all cell types in the adult organism, including the germ line [39]. Induced reprogramming of somatic cells to the pluripotent stem cell state may allow the development of in vitro models of human disease and could provide mechanisms for the generation of patient-specific cells of therapeutic interest $[39,56]$. In human AF cells, the pluripotency can be induced rapidly and more efficiently for production of iPS cells [31,32]. The iPS cell generated from embryonic fibroblasts in bovines exhibited part of stem cell markers, as evidenced by Nanog, SSEA positivity but SSEA3 and TRA negativity [19].

The potential of iPS cell technology is enormous, but this technology is still in its infancy in animals. To realize the full application of iPS cells, it will be essential to improve the methodologies for iPS cell generation. Further, the stem cells derived from fetal extra-embryonic sources, mostly of the mesenchymal type, have the advantage that they exhibit higher proliferation efficiency. Most of these cells don't require feeder that excludes the possibilities of mixing the cells from other species. Moreover, the fetal stem cells display negligible immunogenicity and teratoma formation is also not observed, while involving no ethical concerns.

\section{Fetal Stem Cells in Animal Health and Production}

The last two decades has seen a surge of interest in the research and clinical availability of stem cell treatments. Innovative techniques of cell and tissue processing, based on tissue engineering, have been developed. Cell expansion and tissue reconstruction through ex vivo cultures are core processes used to produce engineered tissues with sufficient structural integrity and functionality [23].

The development of human and murine ES cell lines has been described in the literature in a number of peer reviewed publications. Fetal stem cells expressing pluripotency markers, provides strong support to the notion that these cells may be biological homologous to pluripotent ES 
cells. There are some reports describing the derivation of putative fetal stem cells in domestic ungulates, and pet animals with varying results. Commercial companies are emerging with strategies to enhance stem cell research and applications in veterinary health and livestock production. Formed in 2002, Vet-Stem Inc. (www.vet-stem.com) is the first company to offer regenerative medicine to veterinarians. In 2003, the company introduced the first veterinary stem cell service in the United States. Its technology has been used to treat tendon, ligament, and joint injuries in more than 3,000 horses and more than 1,000 dogs.

The use of fetal and adult stem cells in veterinary medicine is of great promise and is likely to show rapid uptake, as commercially available safe treatments with adipose and bone marrow-derived cells become more widespread. The features and the potential therapeutic properties of fetal stem cells from various sources described here are expected to be studied in more depth and then implemented at the clinical level following international guidelines.

Published literature on the clinical use of stem cells is limited to a small number of studies in canine and equine musculoskeletal conditions. Cell-based therapies with embryonic, fetal, adult, or iPS cells are thought to have great potential for augmenting assisted reproduction and treatment of several degenerative diseases, which currently are without effective therapy. For instance, bone fracture, as well as damaged cartilage, tendons and ligaments heal poorly in horses. Equine iPS cells bring new therapeutic potential to the veterinary field, and open up the opportunity to validate stem-cell based therapies before clinical studies in humans [36]. As well, stem-cell based studies using the horse as a model more closely replicate human illnesses, when compared with studies in mice [36]. Therefore, the use of reprogrammed cells in these animals may help enhance long-term tissue repair.

\section{Stem Cells in Poultry Production}

Moreover, poultry production is a well-organized industry. The chicken eggs have been used in the manufacture of vaccines for more than three decades. One of the remarkable advantages of the avian embryo is its accessibility and availability in plenty. Since the avian embryo is self-contained in a calcified eggshell, it lends itself to direct manipulation. However, compared to other livestock species, the overall progress towards establishing avian stem cells is slow. Advances in culturing avian embryos have also led to developments in avian stem cells. A modern layer lays approximately 300 eggs an year, and the egg white alone contains four grams of protein. The hen takes much less time to reach sexual maturity than any other livestock species (http://www.poulvet.com/poultry/articles/ 3.ph, Oct. 1, 2011). Nevertheless, only a few laboratories were involved in research and development in avian ES as well as EG cells [44]. The main impetus for the isolation and culture of avian stem cells is the hope that they could be used to generate transgenic birds.

Avian ES cells differentiate into embryoid bodies (EB) as well as various somatic cell lineages, and can be used for a variety of applications including production of chimera or transgenic birds for biopharming (Fig. 5). An interesting prospect would be to culture stem cells from genetically superior birds and use the cells to generate elite avian chimeras that would appear to be virtually genetically identical.

With adaptations to high-throughput in ovo vaccination technology, it could be possible to generate high-grade avian somatic chimeras, thereby shortening the time needed for conventional poultry breeding programs to generate superior stock [48]. The chicken (Fig. 5) (http://photo-dict. faqs.org/phrase/359/hen.html) in theory, could be a promising live bioreactor for production of recombinant therapeutic proteins and nutraceuticals [13]. The stem cells could be used for in vitro pharmaceutical applications such as human vaccine development, which often requires the use of embryonated eggs, or production of therapeutic proteins for human applications. The ES cells could be developed from transgenic chickens that express a reporter gene [35], thereby providing stem cells with a cell lineage marker that could be traced in vitro and in vivo. Therefore, transgenic chicken holds a tremendous potential to revolutionize the biotechnology industry and would contribute significantly to the national economy. At present, many private research companies have initiated research in the field of avian transgenics to harness this powerful emerging technology (http://www.poulvet.com/poultry/articles/3.ph Oct, 1, 2011). However, development of a stem cell lines and robust methods for production of transgenic birds has been more of a challenge.

\section{Concluding Remarks}

Science and medicine place a lot of hopes in the development of stem cell research and regenerative medicine. Worldwide media reports about stem cell therapies are becoming common as stem cell applications are being pursued in diverse areas including cardiology, orthopaedics, oncology, internal medicine and assisted reproduction. Till date, significant progress has been made in stem cell research and new strategies for somatic cell reprogramming have been developed. In view of the ethical problems in deriving ES cells, the researchers are interested in discovering alternative ways of deriving pluripotent 


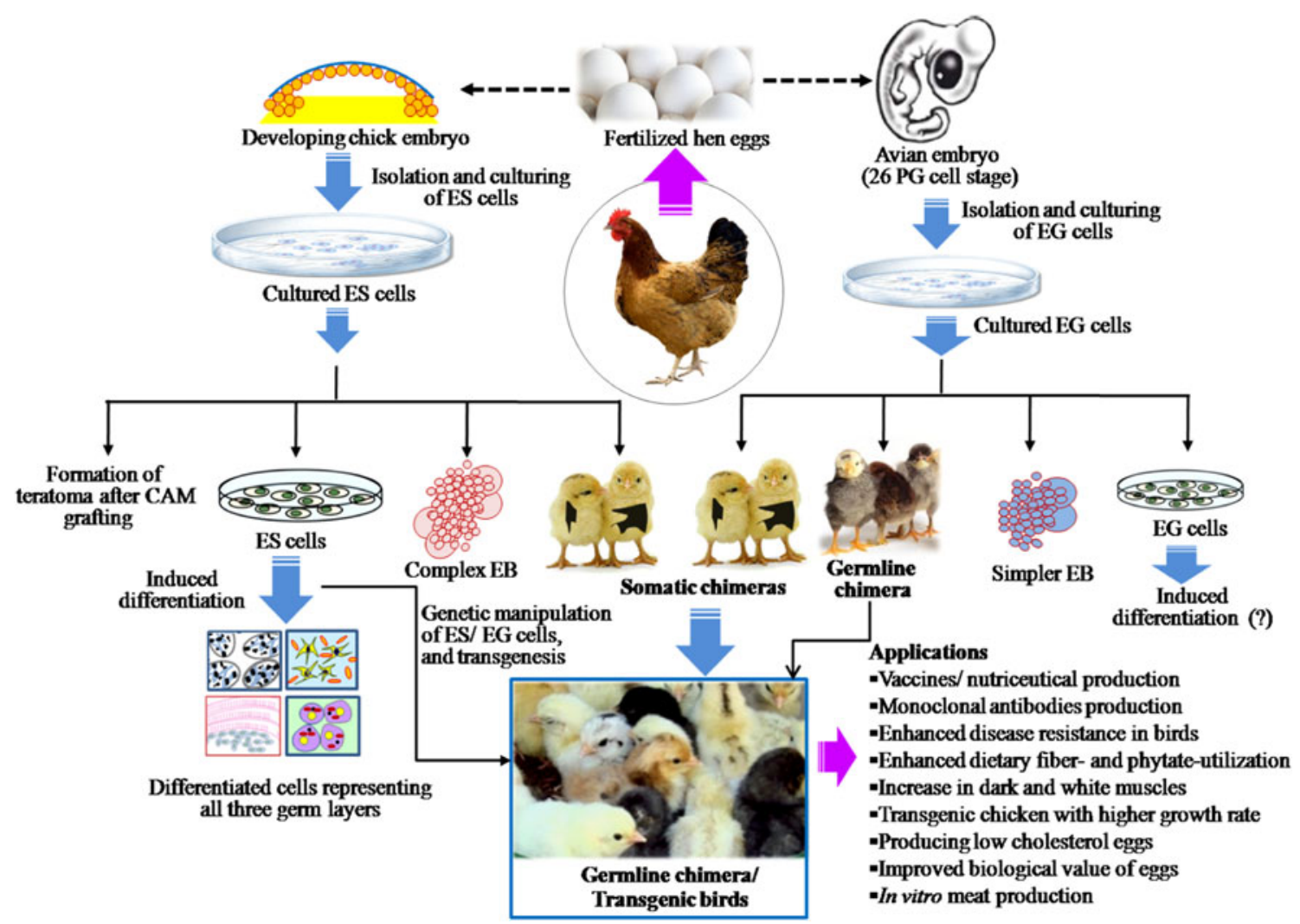

Fig. 5 The prospects of stem cell technology to augment poultry production and enhance food and pharmaceutical production. Transgenic chicken can also be produced by using genetically engineered blastodermal cells and primordial ferm cells

stem cells. Non-embryonic fetal stem cells can be isolated during gestation from many different tissues as well as from a variety of extra embryonic tissues such as AF and placenta. In domestic ungulates as well as poultry, the ES and EG cells and adult stem cell technology are still at initial stages of development. Cells isolated from livestock species might have important application in studies in developmental biology and especially in unravelling appropriate culture conditions and markers for stem cells. Several potential applications of transgenic chickens have been identified and the two main areas include agriculture and healthcare. In addition, although many of the nonembryonic stem cells have demonstrated ES cell-like morphology and expression of some ES cell-specific markers, concerns should be raised over the lack of data regarding long-term culture and maintenance of pluripotency. Ethical concerns in use of animals for production of therapeutic concerns have to be followed strictly.

\section{References}

1. Anderson GB (1992) Isolation and use of embryonic stem cells from livestock species. Anim Biotechnol 3:165-175
2. Azari O, Babaei H, Derakhshanfar A, Nematollahi-Mahani SN, Poursahebi R, Moshrefi M (2011) Effect of transplanted mesenchymal stem cells isolated from Wharton's jelly of caprine umbilical cord on cutaneous wound healing; histopathological evaluation. Vet Res Commun 35:211-222

3. Benirschke K, Kaufman P (2000) Pathology of the human placenta. Springer-Verlag, New York, pp 273-281

4. Carlin R, Davis D, Weiss M, Schultz B, Troyer D (2006) Expression of early transcription factors Oct-4, Sox-2 and Nanog by porcine umbilical cord (PUC) matrix cells. Reprod Biol Endocrinol 4:8

5. Carpenter MK, Rosler E, Rao MS (2003) Characterization and differentiation of human embryonic stem cells. Cloning Stem Cells 5:79-88

6. Chen J, Li Y, Wang L, Zhang Z, Lu D, Lu M, Chopp M (2001) Therapeutic benefit of intravenous administration of bone marrow stromal cells after cerebral ischemia in rats. Stroke 32:1005-1011

7. Chen X, Song XH, Yin Z, Zou XH, Wang LL, Hu H, Cao T, Zheng M, Ouyang HW (2009) Stepwise differentiation of human embryonic stem cells promotes tendon regeneration by secreting fetal tendon matrix and differentiation factors. Stem Cells 27:1276-1287

8. Coli A, Nocchi F, Lamanna R, Iorio M, Lapi S, Urciuoli P, Scatena F, Giannessi E, Stornelli MR, Passeri S (2011). Isolation and characterization of equine amnion mesenchymal stem cells. Cell Biol Int Rep 18(1):art:e00011. doi:10.1042/CBR20110004

9. Cremonesi F, Corradetti B, Lange CA (2011) Fetal adnexa derived stem cells from domestic animal: progress and perspectives. Theriogenology 75:1400-1415

10. Dev K, Gautam SK, Giri SK, Kumar A, Yadav A, Verma V, Kumar P, Singh B (in press) Isolation, culturing and 
characterization of feeder-independent amniotic fluid stem cells in buffalo (Bubalus bubalis). Res Vet Sci. doi:10.1016/j.rvsc.2011. 09.007

11. Dixon JA, Spinale FG (2009) Large animal models of heart failure: a critical link in the translation of basic science to clinical practice. Circ Heart Fail 2:262-271

12. Dowling BA, Dart AJ, Hodgson DR, Smith RK (2000) Superficial digital flexor tendonitis in the horse. Equine Vet $\mathrm{J}$ 32:369-378

13. Fabrice L, Bertrand P (2010) Chicken embryonic stem cells as a non-mammalian embryonic stem cell model. Dev Growth Differ 52:101-114

14. Fauza D (2004) Amniotic fluid and placental stem cells. Best Pract Res Clin Obstet Gynaecol 18:877-891

15. Fong CY, Richards M, Manasi N, Biswas A, Bongso A (2007) Comparative growth behaviour and characterization of stem cells from human Wharton's jelly. Reprod Biomed Online 15:708-718

16. Forraz N, McGuckin CP (2011) The umbilical cord: a rich and ethical stem cell source to advance regenerative medicine. Cell Prolif 44(Suppl 1):60-69

17. Fortier LA, Smith RK (2008) Regenerative medicine for tendinous and ligamentous injuries of sport horses. Vet Clin North Am Equine Pract 24:191-201

18. Hall V (2008) Porcine embryonic stem cells: a possible source for cell replacement therapy. Stem Cell Rev 4:275-282

19. Han X, Han J, Ding F, Cao S, Lim SS, Dai Y, Zhang R, Zhang Y, Lim B, Li N (2011) Generation of induced pluripotent stem cells from bovine embryonic fibroblast cells. Cell Res 21:1509-1512

20. Jeffcott LB, Rossdale PD, Freestone J, Frank CJ, Towers-Clark PF (1982) An assessment of wastage in thoroughbred racing from conception to 4 years of age. Equine Vet J 14:185-198

21. Kader D, Saxena A, Movin T, Maffulli N (2002) Achilles tendinopathy: some aspects of basic science and clinical management. Br J Sports Med 36:239-249

22. Kim J, Lee Y, Kim H, Hwang KJ, Kwon HC, Kim SK, Cho DJ, Kang SG, You J (2007) Human amniotic fluid-derived cells have characteristics of multipotent stem cells. Cell Prolif 40:75-90

23. Kino-Oka M, Taya M (2009) Recent developments in processing systems for cell and tissue cultures toward therapeutic application. J Biosci Bioeng 108:267-276

24. Klemmt PA, Vafaizadeh V, Groner B (2011) The potential of amniotic fluid stem cells for cellular therapy and tissue engineering. Expert Opin Biol Ther 11(10):1297-1314

25. Knaut H, Werz C, Geisler R, The Tübingen 2000 Screen Consortium, Nüsslein-Volhard C (2003) A zebrafish homologue of the chemokine receptor $\mathrm{Cxcr} 4$ is a germ-cell guidance receptor. Nature 421:279-282

26. Koch TG, Berg LC, Betts DH (2008) Concepts for the clinical use of stem cells in equine medicine. Can Vet J 49:1009-1017

27. Kues WA, Petersen B, Mysegades W, Carnwath JW, Niemann H (2005) Isolation of murine and porcine fetal stem cells from somatic tissue. Biol Reprod 72:1020-1028

28. Kunwar PS, Lehmann R (2003) Developmental biology:Germcell attraction. Nature 421:226-227

29. Leeb C, Jurga M, McGuckin C, Moriggl R, Kenner L (2010) Promising new sources for pluripotent stem cells. Stem Cell Rev Rep 6:15-26

30. Li B-C, Sun G-B, Sun H-C, Xu Q, Gao B, Zhou G-Y, Zhao W-M, Wu X-S, Bao W-B, Yu F, Wang K-H, Chen G-H (2008) Efficient generation of transgenic chickens using the spermatogonial stem cells in vivo and ex vivo transfection. Sci China Ser C-Life Sci 51:734-742

31. Li C, Zhou J, Shi G, Ma Y, Yang Y, Gu J, Yu H, Jin S, Wei Z, Chen F, Jin Y (2009) Pluripotency can be rapidly and efficiently induced in human amniotic fluid-derived cells. Hum Mol Genet $18: 4340-4349$
32. Li J-X, Zhang Y, Ma LB, Sun J-H, Yin B-Y (2009) Isolation and culture of bovine mammary epithelial stem cells. J Vet Med Sci 71:15-19

33. Mauro A, Turriani M, Ioannoni A, Russo V, Martelli A, Di Giacinto O, Nardinocchi D, Berardinelli P (2010) Isolation, characterization, and in vitro differentiation of ovine amniotic stem cells. Vet Res Commun 34(Suppl 1):S25-S28

34. Memon IA, Sawa Y, Miyagawa S, Taketani S, Matsuda H (2005) Combined autologous cellular cardiomyoplasty with skeletal myoblasts and bone marrow cells in canine hearts for ischemic cardiomyopathy. J Thorac Cardiovasc Surg 130:646-653

35. Mozdziak PE, Borwornpinyo S, McCoy DW, Petitte JN (2003) Development of transgenic chickens expressing bacterial betagalactosidase. Dev Dyn 226:439-445

36. Nagy K, Sung HK, Zhang P, Laflamme S, Vincent P, AghaMohammadi S, Woltjen K, Monetti C, Michael IP, Smith LC, Nagy A (2011) Induced pluripotent stem cell lines derived from equine fibroblasts. Stem Cell Rev 7:693-702

37. Niemann H, Kues WA (2007) Transgenic farm animals: an update. Reprod Fertil Dev 19:762-770

38. Niemann H, Kuhla B, Flachowsky G (2011) The perspectives for feed efficient animal production. J Anim Sci 89:4344-4363

39. Nowak-Imialek M, Kues WA, Niemann H (2011) Pluripotent stem cells and reprogrammed cells in farm animals. Microsc Microanal 17:474-497

40. Pappa KI, Anagnou NP (2009) Novel source of fetal stem cells: where do they fit on the developmental continuum? Regen Med 4:423-433

41. Park SB, Seo MS, Kang JG, Chae JS, Kang KS (2011) Isolation and characterization of equine amniotic fluid-derived multipotent stem cells. Cytotherapy 13:341-349

42. Parolini O, Soncini M, Evangelista M, Schmidt D (2009) Amniotic membrane and amniotic fluid-derived cells: potential tools for regenerative medicine? Regen Med 4:275-291

43. Perin L, Sedrakyan S, Da Sacco S, De Filippo R (2008) Characterization of human amniotic fluid stem cells and their pluripotential capability. Methods Cell Biol 86:85-99

44. Petitte JN, Liu G, Yang Z (2004) Avian pluripotent stem cells. Mech Dev 121:1159-1168

45. Portmann-Lanz CB, Schoeberlein A, Huber A, Sager R, Malek A, Holzgreve W, Surbek DV (2006) Placental mesenchymal stem cells as potential autologous graft for pre- and perinatal neuroregeneration. Am J Obstet Gynecol 194:664-673

46. Rachakatla RS (2008) Targeted use of umbilical cord matrix stem cells for cancer therapy. PhD Thesis, Kansas State University Manhattan, Kansas

47. Richardson LE, Dudhia J, Clegg PD, Smith R (2007) Stem cells in veterinary medicine- attempts at regenerating equine tendon after injury. Trends Biotechnol 25:409-416

48. Ricks CA, Mendu N, Phelps PV (2003) The embryonated egg: a practical target for genetic based advances to improve poultry production. Poult Sci 82:931-938

49. Rossdale PD, Hopes R, Digby NJ, Offord K (1985) Epidemiological study of wastage among racehorses 1982 and 1983. Vet Rec 116:66-69

50. Samandari MH, Abidi S, Khoshzaban A, Aghazadeh S, Dihimi P, Torbaghan SS, Keshel SH, Shahabi Z (2011) Human amniotic membrane, best healing accelerator, and the choice of bone induction for vestibuloplasty technique (an animal study). Transpalnt Res Risk Manage 3:1-8

51. Sapin V, Souteyrand G, Bonnin N, Gallot D, Blanchon L, Chiambaretta F (2011) Therapeutic use of amniotic membranes and their derivate cells. Gynecol Obstet Fertil 39:388-390

52. Sharma P, Maffulli N (2006) Biology of tendon injury: healing, modeling and remodeling. $\mathrm{J}$ Musculoskelet Neuronal Interact 6:181-190 
53. Simioniuc A, Campan M, Lionetti V, Marinelli M, Aquaro GD, Cavallini C, Valente S, Di Silvestre D, Cantoni S, Bernini F, Simi C, Pardini S, Mauri P, Neglia D, Ventura C, Pasquinelli G, Recchia FA (2011) Placental stem cells pre-treated with a hyaluronan mixed ester of butyric and retinoic acid to cure infarcted pig hearts: a multimodal study. Cardiovasc Res 90:546-556

54. Singh B, Chauhan MS, Singla SK, Gautam SK, Verma V, Singh AK, Manik RS, Sodhi M, Mukesh M (2009) Reproductive biotechniques in buffalo: status, prospects and challenges. Reprod Fertil Dev 14:499-507

55. Singh J, Mann A, Singh V, Duhan JS, Yadav PS (2010) Buffalo umbilical cord matrix as possible source of stem cells. In: International buffalo conference on "optimizing buffalo productivity through conventional and novel technologies" held during Feb 1-4, 2010 at NASC Complex, New Delhi

56. Singh B, Gautam SK, Chauhan MS, Singla SK, Kumar S, Kumar V, Yadav PS (2011) Cellular reprogramming-advances and opportunities for applications in veterinary and animal sciences. In: Leon Berhardt V (ed) Advances in medicine and biology, vol 16. Nova Science Publishers, Inc. 400 Oser Avenue, New York

57. Solomon A, Wajngarten M, Alviano F, Anteby I, Elchalal U, Pe'er J, Levi-Schaffer F (2005) Suppression of inflammatory and fibrotic responses in allergic inflammation by the amniotic membrane stromal matrix. Clin Exp Allergy 35:941-948

58. Sritanaudomchai H, Pavasuthipaisit K, Kitiyanant Y, Kupradinun P, Mitalipov S, Kusamran T (2007) Characterization and multilineage differentiation of embryonic stem cells derived from a buffalo parthenogenetic embryo. Mol Reprod Dev 74:1295-1302

59. Starz-Gaiano M, Lehmann R (2001) Moving towards the next generation. Mech Dev 105:5-18

60. Takahashi K, Yamanaka S (2006) Induction of pluripotent stem cells from mouse embryonic and adult fibroblast cultures by defined factors. Cell 126:663-676
61. Talbot NC, Blomberg LA (2008) The pursuit of ES cell lines of domestic ungulates. Stem Cell Rev 4:235-254

62. Talbot NC, Caperna TJ, Edwards JL, Garrett W, Wells KD, Ealy AD (2000) Bovine blastocyst-derived trophectoderm and endoderm cell cultures: interferon tau and transferrin expression as respective in vitro markers. Biol Reprod 62:235-247

63. Taylor SE, Smith RK, Clegg PD (2007) Mesenchymal stem cell therapy in equine musculoskeletal disease: scientific fact or clinical fiction? Equine Vet J 39:172-180

64. Tecirlioglu RT, Trounson AO (2007) Embryonic stem cells in companion animals (horses, dogs and cats): present status and future prospects. Reprod Fertil Dev 9:740-747

65. Verma V, Gautam SK, Singh B, Manik RS, Palta P, Singla SK, Goswami SL, Chauhan MS (2007) Isolation and characterization of embryonic stem cell-like cells from in vitro-produced buffalo (Bubalus bubalis) embryos. Mol Reprod Dev 74:520-529

66. Watts AE, Yeager AE, Kopyov OV, Nixon AJ (2011) Fetal derived embryonic-like stem cells improve healing in a large animal flexor tendonitis model. Stem Cell Res Ther 2:4

67. Wells DN, Oback B, Laible G (2003) Cloning livestock: a return to embryonic cells. Trends Biotechnol 21:428-432

68. Yadav PS, Kues WA, Herrmann D, Carnwath JW, Niemann H (2005) Bovine ICM derived cells express the OCT-4 ortholog. Mol Reprod Dev 72:182-190

69. Yadav PS, Tokas J, Sharma RK, Singh I, Sethi RK (2008) Buffalo amniotic fluid, umbilical cord matrix and early fetal explants as possible source of adult stem cells. IX Annual conference of Indian society of animal genetics and breeding. July 3-4, Delhi

70. Yadav PS, Mann A, Singh V, Yashveer S, Sharma RK, Singh I (2011) Expression of pluripotency genes in buffalo (Bubalus bubalis) amniotic fluid cells. Reprod Domest Anim 46:705-711 